\title{
HEMAGGLUTININS AND HEMOLYSINS FOR ERYTHROCYTES SENSITIZED WITH TUBERCULIN IN PULMONARY TUBERCULOSIS ${ }^{1}$
}

\author{
By WENDELL H. HALL AND ROBERT E. MANION \\ (From the Veterans Administration Hospital and the Department of Medicine, The Medical \\ School, University of Minnesota, Minneapolis, Minn.)
}

(Submitted for publication August 8, 1951; accepted September 24, 1951)

The recent discovery by Middlebrook $(1,2)$ that sera from tuberculous animals and human beings are capable of agglutinating and lysing erythrocytes previously treated with extracts of tubercle bacilli has aroused considerable interest. In a brief period of time several clinical evaluations of the hemagglutination test have appeared in print $(3,4)$. As yet only one preliminary report has appeared concerning its hemolytic modification (4). It is the purpose of the present paper to report our clinical experience with both tests during the past year. More than 1000 tests have been carried out in that period with sera obtained from well over 100 patients having active tuberculosis and a similar number of adults not having active tuberculosis.

\section{MATERIAL}

The tuberculous patients selected for this study were hospitalized either on the Tuberculosis Service of the Minneapolis Veterans Administration Hospital or at the Minneapolis General Hospital. Pulmonary tuberculosis was predominant, and in most cases the disease was extensive. The diagnosis was proved in all cases roentgenologically and by isolation of $M$. tuberculosis from the sputum or gastric washings. A total of 151 patients having active pulmonary tuberculosis was studied; several of the patients had extra-pulmonary dissemination of their tuberculosis, but in most the pulmonary infection was predominant. The control group included 128 subjects having a negative chest roentgenogram. The group included college students, physicians, medical technicians, and a few patients having non-tuberculous diseases. All were tested for tuberculin sensitivity, ${ }^{2}$ and 61 were found

\footnotetext{
1 Sponsored by the Veterans Administration and published with the approval of the Chief Medical Director. The statements and conclusions published by the authors are the result of their own study and do not necessarily reflect the opinion or policy of the Veterans Administration.

$20.1 \mathrm{ml}$. of $1: 1000$ dilution of old tuberculin intradermally.
}

positive while 67 were negative. Thirty-four of the latter group were entering freshmen students at the University of Minnesota. No individual was included who had received a Mantoux test during the previous three months in order to avoid antibody titers resulting from such antigens (5).

\section{METHODS}

Hemagglutinins. The method of Middlebrook and Dubos (1) was employed. Heterophile antibodies were absorbed from the heat-inactivated sera by the method of Middlebrook (2). Sheep cells were collected in modified Alsever's solution, and streptomycin (1000 units per ml.) was added as a preservative. Old tuberculin, $4 \times$ concentrated, $^{3}$ was used to sensitize the sheep cells as recommended by Scott and Smith (6). Sensitized sheep cells were added to serial twofold dilutions (1:4 through $1: 256)$ of the absorbed sera. Appropriate controls were included. After incubation for two hours at $37^{\circ} \mathrm{C}$., and overnight at room temperature, the degree of hemagglutination was recorded after resuspension.

Hemolysins. The method of Middlebrook (2) was used and differed little from that given above. Fresh guinea pig serum diluted 1:3 and absorbed with sheep cells was used as the source of complement. After addition of tuberculin-sensitized sheep erythrocytes and complement to the serially diluted patient's serum, incubation was carried out at $37^{\circ} \mathrm{C}$. for one hour. The degree of hemolysis was then recorded.

Coombs Hemolysins. A sensitive hemolytic modification of the indirect Coombs test (7) was devised (4). Human (group $\mathrm{O}, \mathrm{Rh}$ negative) erythrocytes were used in place of sheep cells in order that difficulties with heterophile antibodies might be avoided. Serial twofold dilutions of heat-inactivated immune serum were prepared (1:2 through $1: 128)$. To $0.1 \mathrm{ml}$. of each was added $0.1 \mathrm{ml}$. of a 2 per cent suspension of tuberculinsensitized erythrocytes. After incubation for one hour at $37^{\circ} \mathrm{C}$. the erythrocytes were thrown down by high speed centrifugation and carefully washed three times with ten volumes of buffered 0.8 per cent saline solution ( $\mathrm{pH} 7.0$ ). After resuspension to their original volume in saline, the erythrocytes were added to an equal volume

${ }^{8}$ Lot no. 2725-2 obtained from Lederle Laboratories, Pearl River, N. Y., through the courtesy of Dr. H. D. Piersma. 
of Coombs anti-human globulin rabbit serum 4 and incubated one hour at $37^{\circ} \mathrm{C}$. Fresh guinea pig complement 5 (0.05 ml. 1:3 dilution) was then added and a final incubation carried out for one hour at $37^{\circ} \mathrm{C}$. Control tubes were included in which Coombs serum was replaced by heat-inactivated, absorbed normal rabbit serum as well as a control tube in which unsensitized erythrocytes replaced the tuberculin-treated human cells. Hemolysis was recorded immediately after the final incubation.

"Blocking" antibodies. Two methods were used to detect the presence of "blocking" antibodies. In method No. 1 an equal quantity of the suspected blocking serum was added to serial twofold dilutions of an immune serum having a high antibody titer. Hemagglutinin and hemolysin tests were then performed in the usual manner. In method No. 2 the reverse procedure was carried out. That is, the amount of the immune serum was kept constant and the quantity of blocking serum varied.

\section{RESULTS}

The hemagglutinin antibody titers of $151 \mathrm{pa-}$ tients having active pulmonary tuberculosis are shown in Table I. The median titer was $1: 8$; only

4 Prepared by Ortho Pharmaceutical Corp., Raritan, N. J.

- Absorbed with human (group $\mathrm{O}, \mathrm{Rh}$ negative) erythrocytes (2).

TABLE I

Anti-tuberculin hemagglutinins and hemolysins

\begin{tabular}{|c|c|c|c|c|c|c|}
\hline \multirow{3}{*}{ Antibody titer } & \multirow{2}{*}{\multicolumn{2}{|c|}{$\begin{array}{l}\text { Active pulmonary } \\
\text { tuberculosis }\end{array}$}} & \multicolumn{4}{|c|}{ Control subjects } \\
\hline & & & \multicolumn{2}{|c|}{ +Mantoux } & \multicolumn{2}{|c|}{-Mantoux } \\
\hline & No. & $\%$ & No. & $\%$ & No. & $\%$ \\
\hline $\begin{array}{c}\text { Hemagglutinins } \\
>128 \\
128 \\
64 \\
32 \\
16 \\
8 \\
4 \\
<4 \\
\text { Total }\end{array}$ & $\begin{array}{r}4 \\
1 \\
9 \\
21 \\
28 \\
22 \\
31 \\
35 \\
151\end{array}$ & $\begin{array}{c}2.6 \\
0.6 \\
5.9 \\
13.9 \\
18.5 \\
14.6^{*} \\
20.5 \\
23.2\end{array}$ & $\begin{array}{r}0 \\
0 \\
0 \\
3 \\
4 \\
6 \\
9 \\
39 \\
61\end{array}$ & $\begin{array}{c}0 \\
0 \\
0 \\
4.9 \\
6.5 \\
9.8 \\
14.7 \\
63.9^{*}\end{array}$ & $\begin{array}{r}0 \\
0 \\
1 \\
0 \\
2 \\
4 \\
20 \\
40 \\
67\end{array}$ & $\begin{array}{l}0 \\
0 \\
1.5 \\
0 \\
3.0 \\
6.0 \\
29.8 \\
59.7^{*}\end{array}$ \\
\hline $\begin{array}{r}\text { Hemolysins } \\
>128 \\
128 \\
64 \\
32 \\
16 \\
8 \\
4 \\
<4 \\
\text { Total }\end{array}$ & $\begin{array}{r}18 \\
8 \\
16 \\
20 \\
17 \\
15 \\
12 \\
9\end{array}$ & $\begin{array}{r}15.6 \\
7.0 \\
13.9 \\
17.4^{*} \\
14.7 \\
13.0 \\
10.4 \\
7.8\end{array}$ & $\begin{array}{r}1 \\
1 \\
1 \\
7 \\
5 \\
7 \\
3 \\
25 \\
50\end{array}$ & $\begin{array}{r}2.0 \\
2.0 \\
2.0 \\
14.0 \\
10.0 \\
14.0 \\
6.0 \\
50.0^{*}\end{array}$ & $\begin{array}{r}1 \\
0 \\
2 \\
3 \\
7 \\
7 \\
8 \\
34 \\
62\end{array}$ & $\begin{array}{c}1.6 \\
0 \\
3.2 \\
4.8 \\
11.3 \\
11.3 \\
12.9 \\
54.8^{*}\end{array}$ \\
\hline
\end{tabular}

* Median.
9.3 per cent had a titer greater than $1: 32$. In 128 subjects having a negative chest roentgenogram the median hemagglutinin titer was less than $1: 4$. There was no difference in the median titer of the control subjects having a positive Mantoux test as compared with those having a negative Mantoux test. There was no clinical evidence that any of these control subjects had active tuberculosis, yet several had a hemagglutinin titer of $1: 8$ or higher.

The hemolysin antibody titers of the majority of these subjects were determined and are also presented in Table I. The median hemolysin titer of 115 patients having active pulmonary tuberculosis was $1: 32$ and in 112 control subjects having a negative chest roentgenogram was less than $1: 4$. The presence of tuberculin hypersensitivity appeared to have no influence upon the median hemolysin titer of the control subjects. A considerable number of the control subjects had a hemolysin titer of $1: 32$ or greater, particularly among those whose Mantoux test was positive.

We have published elsewhere preliminary data concerning the simultaneous determination of hemagglutinin and hemolysin titers (4). In 68.7 per cent of 103 patients having active pulmonary tuberculosis and 105 healthy control subjects, the two tests revealed antibody titers which did not differ by more than one dilution. In 29.3 per cent the hemolysin titer exceeded the other by more than one dilution, and in only 1.9 per cent was the hemagglutinin titer significantly greater than the hemolysin titer. Serial observations indicated that the latter phenomenon was usually only transient, and complement titration proved that it was not due to the presence of an anti-complementary substance.

All patients included in this study had active pulmonary tuberculosis. The extent of their pulmonary disease did not appear to influence their antibody titer. In a group of 127 patients tested for hemagglutinins, there were 13 with minimal, 53 with moderately advanced, and 61 with far advanced pulmonary tuberculosis. The median hemagglutinin titer was $1: 4$ in the group having far advanced pulmonary tuberculosis, and $1: 8$ in each of the other two groups. In a study of 103 of the same patients the hemolysin test yielded a median titer of 1:32 in each of the three groups.

As can be seen in Table I, patients having active pulmonary tuberculosis frequently possessed 
TABLE II

Anti-tuberculin Coombs hemolysins in patients having active pulmonary tuberculosis but negative Middlebrook tests $(1,2)$

\begin{tabular}{|c|c|c|c|c|c|c|c|c|}
\hline \multirow{2}{*}{ Subjects } & \multicolumn{8}{|c|}{ Serum dilutions (reciprocal) } \\
\hline & $C^{*}$ & 2 & 4 & 8 & 16 & 32 & 64 & 128 \\
\hline \multirow{3}{*}{$\begin{array}{l}\text { Normal } \\
\text { Patients } \\
\text { O. Lo. } \\
\text { Wo. } \\
\text { O'C. } \\
\text { Wa. } \\
\text { Re. } \\
\text { Bo. }\end{array}$} & \multicolumn{8}{|c|}{$\begin{array}{l}\text { With Coombs anti-human globulin } \\
\text { rabbit serum }\end{array}$} \\
\hline & $\begin{array}{l}0^{* *} \\
0 \\
0 \\
0 \\
0 \\
0 \\
0\end{array}$ & $\begin{array}{l}0 \\
4+ \\
4+ \\
4+ \\
4+ \\
4+ \\
1+\end{array}$ & $\begin{array}{l}0 \\
4+ \\
4+ \\
4+ \\
4+ \\
4+ \\
1+\end{array}$ & $\begin{array}{l}0 \\
4+ \\
4+ \\
4+ \\
4+ \\
4+ \\
1+\end{array}$ & $\begin{array}{l}0 \\
4+ \\
4+ \\
4+ \\
4+ \\
3+ \\
1+\end{array}$ & $\begin{array}{l}0 \\
4+ \\
4+ \\
4+ \\
3+ \\
1+ \\
1+\end{array}$ & $\begin{array}{l}0 \\
4+ \\
3+ \\
3+ \\
2+ \\
1+ \\
1+\end{array}$ & $\begin{array}{l}0 \\
3+ \\
2+ \\
2+ \\
2+ \\
0 \\
0\end{array}$ \\
\hline & \multicolumn{8}{|c|}{ With normal rabbit serum (control) } \\
\hline $\begin{array}{l}\text { Normal } \\
\text { Patients } \\
\text { O. Lo. } \\
\text { Wo. } \\
\text { O'C. } \\
\text { Wa. } \\
\text { Re. } \\
\text { Bo. }\end{array}$ & $\begin{array}{l}0 \\
\\
0 \\
0 \\
0 \\
0 \\
0 \\
0\end{array}$ & $\begin{array}{l}0 \\
1+ \\
2+ \\
0 \\
0 \\
0 \\
0\end{array}$ & $\begin{array}{l}0 \\
1+ \\
2+ \\
0 \\
0 \\
0 \\
0\end{array}$ & $\begin{array}{l}0 \\
1+ \\
0 \\
0 \\
0 \\
0 \\
0\end{array}$ & $\begin{array}{l}0 \\
1+ \\
0 \\
0 \\
0 \\
0 \\
0\end{array}$ & $\begin{array}{l}0 \\
0 \\
0 \\
0 \\
0 \\
0 \\
0\end{array}$ & $\begin{array}{l}0 \\
0 \\
0 \\
0 \\
0 \\
0 \\
0\end{array}$ & $\begin{array}{l}0 \\
0 \\
0 \\
0 \\
0 \\
0 \\
0 \\
0\end{array}$ \\
\hline
\end{tabular}

* Unsensitized sheep cell control.

${ }^{* *} 0$ to $4+=$ hemolysis after one hour at $37^{\circ} \mathrm{C}$.

little or no hemagglutinin in their serum and somewhat less often lacked hemolysin as well. An exhaustive search for "blocking" antibodies in such sera largely failed. In no instance were we able to disclose blocking of hemagglutinins, and the serum of only one patient inhibited the hemolytic activity of a potent immune serum (4). The addition of bovine albumin or normal human serum in a final concentration of 15 per cent, moreover, did not increase the hemagglutinin or hemolysin activity of low titer sera obtained from patients having active pulmonary tuberculosis.

The addition of Coombs anti-human globulin rabbit serum to sera containing little or no hemagglutinin activity did not substantially increase the hemagglutinin titer of the latter. Coombs antihuman globulin rabbit serum, however, did disclose hemolysins in high titer in almost all sera obtained from patients having active pulmonary tuberculosis even though the Middlebrook test was negative (Table II). Control tests using normal rabbit serum in place of Coombs serum were essentially negative and indicated that the hemolysis was produced by specific human anti-tuberculin hemolytic antibody.

\section{DISCUSSION}

The technical aspects of the Middlebrook tests have been discussed elsewhere and need no further emphasis (8). It should be noted, however, that the hemolytic test is quicker and much easier to read than the hemagglutination test. The data presented in Table I, moreover, indicate that the hemolytic test is a more sensitive and no less specific test for anti-tuberculin antibody in human sera.

As demonstrated in Table III, in our hands neither the hemagglutination nor the hemolysis test has shown as great sensitivity and specificity for active tuberculosis as that reported by Rothbard, Dooneief, and Hite (3). It can be readily seen from the table that our results are essentially in agreement with the data given by most other investigators who have used the hemagglutination test. The hemagglutination test is more likely to be positive in a titer of $1: 8$ or greater in the presence of active pulmonary tuberculosis than in subjects whose chest roentgenogram reveals no evidence of tuberculosis. Yet in an individual patient, the test cannot be relied upon by itself as an index of the extent or activity of tuberculosis. In our studies the test was "negative" in 43.9 per cent of 151 patients whose pulmonary tuberculosis was active. Hemagglutinins and hemolysins were found more often in a significant $\operatorname{titer}^{6}$ in the serum of healthy adults whose tuberculin skin test was positive than in those who were not hypersensitive. Even a minimal sub-clinical pulmonary or extrapulmonary tuberculous lesion may suffice to provoke anti-tuberculin antibodies. In many the presence of these antibodies remains unexplained.

Middlebrook (2) came to the conclusion that human anti-tuberculin hemagglutinin and hemolysin were not identical since their respective titers varied at random in a small group of immune sera. Our own data gathered from a large number of human sera revealed a close correlation between the two; the hemolysin titer frequently exceeded the hemagglutinin titer, but rarely was the hemag-

6 A titer of 1:8 was taken to be significant for hemagglutinins and 1:32 for hemolysins. 
TABLE III

Summary of results of Middlebrook tests $(1,2)$ for anti-tuberculin antibodies in human tuberculosis

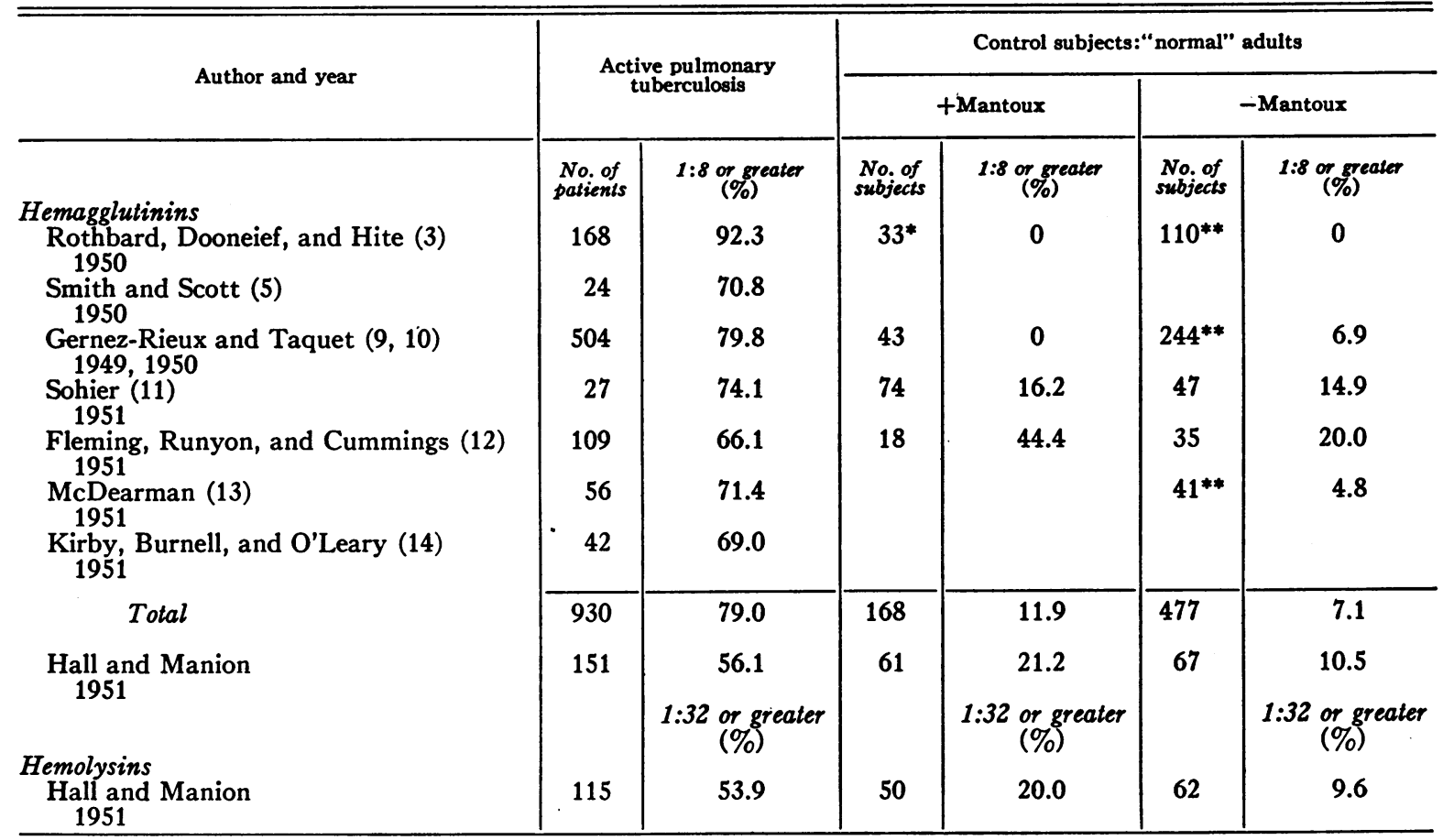

* "Cured tbc." ** "Normal"

glutinin titer the greater by more than one dilution.

Our data do not permit an evaluation of the effect of tuberculous activity upon antibody titer since the disease was active in the great majority of our patients. The median antibody titer was not significantly influenced, however, by the extent of the pulmonary tuberculosis. In patients with far advanced pulmonary tuberculosis the median hemagglutinin titer was slightly less than in patients whose pulmonary disease was less extensive. Sufficient sera from patients with predominantly extrapulmonary tuberculosis have not been tested to permit reliable conclusions.

Hemagglutinins and hemolysins were frequently low in titer and occasionally absent in some patients with active pulmonary tuberculosis. This was not due to the presence of "blocking" antibodies. Nor did such sera contain demonstrable anti-complementary substances. The addition of protein did not disclose greater antibody activity. The addition of Coombs anti-human globulin rabbit serum, however, did disclose anti-tuberculin hemolysin in almost all such sera in high titer (Table II). These sera apparently contained "incomplete" antibody which was capable of unit- ing with tuberculin adsorbed upon erythrocytes, yet was incapable of agglutinating the cells. Sera of this type also were not able to bind complement in the presence of tuberculin-sensitized erythrocytes; this probably accounts for their low hemolytic activity. Such sera did cause slow hemolysis without complement being bound (8). The slight hemolytic activity of these sera for tuberculin-sensitized erythrocytes was due to an "incomplete" anti-tuberculin antibody. The latter was proved by means of a hemolytic modification of the indirect Coombs test (Table II). The lack of "blocking" activity by these sera was an unexpected finding. Despite its union with tuberculin, the antibody in these sera apparently did not block the receptors for "complete" anti-tuberculin antibody. We have likewise found with anti-Brucella sera that Coombs serum is a more sensitive indicator of "incomplete" antibody than are "blocking" tests (unpublished studies).

The reason for the occurrence of "incomplete" antibodies in human tuberculosis has not been disclosed. They have never been found in normal adults and have been associated particularly with chronic, far advanced, pulmonary tuberculosis. 
A similar but somewhat different phenomenon has been produced by hyper-immunization of rabbits with tuberculin $(4,8)$. Anti-tuberculin antibodies appeared promptly after weekly intravenous injection of large doses of tuberculin. After several weeks titers of anti-tuberculin antibodies declined gradually. Ultimately even Coombs hemolysins disappeared and did not reappear after further tuberculin immunization. The rabbits, however, remained capable of responding to other unrelated antigens (8). The disappearance of anti-tuberculin antibodies was not the result of replacement by "incomplete" antibody. It appeared to be due to an immunologic "paralysis" similar to that reported by Felton (15) in mice immunized with large amounts of pneumococcus polysaccharide. Since human tuberculosis is usually a very chronic infection, it is possible that excess antigen liberated over a long period of time may contribute in a similar manner to the paucity of antibodies in some patients.

\section{SUM MARY AND CONCLUSIONS}

1. Hemagglutinins for tuberculin-sensitized sheep cells were found in a titer of $1: 8$ or greater in the serum of 56.1 per cent of 151 patients having active pulmonary tuberculosis, and in 21.2 per cent of 61 tuberculin-positive as well as 10.5 per cent of 67 tuberculin-negative healthy adults.

2. Anti-tuberculin hemolysins were found in a titer of $1: 32$ or greater in the serum of 53.9 per cent of 115 of the same tuberculous patients, in 20 per cent of 50 tuberculin-positive controls, and in 9.6 per cent of 62 tuberculin-negative controls.

3. Studies of 208 human sera revealed a close correlation between anti-tuberculin hemagglutinin and hemolysin titers. The hemolytic test was the more sensitive indicator of anti-tuberculin antibody.

4. Anti-tuberculin hemolysins were disclosed in the serum of nearly all patients having active pulmonary tuberculosis by a modification of the indirect Coombs test even though the hemagglutination and hemolysis tests of Middlebrook were negative.

5. The Coombs hemolysin appeared to be an "incomplete" antibody incapable of agglutinating tuberculin-sensitized erythrocytes or of fixing complement yet able to unite with the tuberculin.

6 . With the antigens available none of these tests can be regarded as sufficiently reliable for widespread use in detecting the presence of active tuberculosis unless rigidly controlled by other accepted diagnostic criteria. They cannot supplant allergic, bacteriologic, and radiologic methods in the diagnosis.

\section{REFERENCES}

1. Middlebrook, G., and Dubos, R. J., Specific serum agglutination of erythrocytes sensitized with extracts of tubercle bacilli. J. Exper. Med., 1948, 88, 521.

2. Middlebrook, G., A hemolytic modification of the hemagglutination test for antibodies against tubercle bacillus antigens. J. Clin. Invest., 1950, 29, 1480.

3. Rothbard, S., Dooneief, A. S., and Hite, K. E., Practical application of a hemagglutination reaction in tuberculosis. Proc. Soc. Exper. Biol. \& Med., 1950, 74, 72.

4. Hall, W. H., Manion, R., and Johnson, D. W., Clinical and experimental studies of the hemagglutination and hemolysis tests for anti-tuberculin antibodies. Tr. Tenth V. A. Army Navy Conf. on Chemotherapy of Tuberc., 1951, 176.

5. Smith, D. T., and Scott, N. B., Clinical interpretation of the Middlebrook-Dubos hemagglutination test. Am. Rev. Tuberc., 1950, 62, 121.

6. Scott, N. B., and Smith, D. T., A simple modification of the Middlebrook and Dubos hemagglutination test for serum antibodies to products of tubercle bacilli. J. Lab. \& Clin. Med., 1950, 35, 303.

7. Coombs, R. R. A., Mourant, A. E., and Race, R. R., A new test for the detection of weak and "incomplete" Rh agglutinins. Brit. J. Exper. Path., 1945, 26, 255.

8. Hall, W. H., Antibodies in tuberculosis. Bull. U. of Minn. Hosp., 1951, 22, 557.

9. Gernez-Rieux, C., and Taquet, A., Sur une réaction spécifique d'agglutination d'hématies sensibilisées, et sur son application au diagnostic de la tuberculose humaine. Bull. Acad. nat. méd., 1949, 133, 556.

10. Gernez-Rieux, C., and Taquet, A., La réaction d'hémagglutination dans la tuberculose. Ann. Inst. Pasteur, Lille, 1950, 3, 1.

11. Sohier, R., Réaction d'hémagglutination, type Dubos Middlebrook réalisée avec une tuberculine purifée; résultats obtenus. Ann. Inst. Pasteur, 1950, 78, 283.

12. Fleming, J. W., Runyon, E. H., and Cummings, M. M., An evaluation of the hemagglutination test for tuberculosis. Am. J. Med., 1951, 10, 704.

13. McDearman, S. C., Hemagglutination tests in tuberculosis. Tr. Tenth V. A. Army Navy Conf. on Chemotherapy of Tuberc., 1951, 173.

14. Kirby, W. M. M., Burnell, J. M., and O'Leary, B., Evaluation of the hemagglutination reaction in the diagnosis of active tuberculosis. Am. Rev. Tuberc., 1951, 64, 71.

15. Felton, L. D., The significance of antigen in animal tissues. J. Immunol., 1949, 61, 107. 